\title{
Interaction of Islam with Local Culture
}

\author{
Zayadi Hamzah \\ IAIN Syaikh Abdurahman Shidik Bangka Belitung \\ zayadihamzah@gmail.com
}

\begin{abstract}
To understand the social and religious phenomena associated with Islamic relations with local culture in the rite of the passage of the family in general with respect to the scope of religious theory as a cultural or religious subsystem as social reality, where religion (Islam) is a social reality confronted with the process of interaction of Islam with the local culture in which Islam is embraced.The process of interaction of Islam with local culture in this study is expected to give birth to acculturation, assimilation, accommodation, conflict, and integration. This process looks at how acculturation, assimilation, accommodation, conflict, and integration exist between Islam and local culture in a social constructivist framework by focusing on what lies behind actions, from the various rituals of the family life cycle. It is assumed that Islamic relations with local culture will occur in several forms: first: the possibility of coexistence or adhesion between Islam and Rejang culture without mutual intervention and interruption; second: the possibility of integration or cohesion whether in the form of Islamic permeation into local culture or adaptation of local culture to Islam, both symbolically and substantially, and third: the possibility of conflict between Islam and local culture both latent and manifest.
\end{abstract}

Keyword: Interraction, Islam; Local Culture

\section{Introduction}

The creation of human is the realization of his caliphate, in the form of a variety of looks and potentials, in language, color, ethnicity, social status, and so forth. In the Sufistic tradition the phenomenon of diversity is referred to as "Tajally", the glorification of divine majesty ${ }^{1}$. So the color and cultural character of muslims in each locality is quite diverse. Sayyed Hossain Nasr ${ }^{2}$ mentions at least there are three root issues that can form

\footnotetext{
1 More detail philosophical explanation of the concept of the formation of creatures in the concept of philosophy, see the order of the Qur'an, Too of Islam, (Bandung: Mizan 2005), p. 47-50
}

2 See his creation, Islamic Life and Thoughts, (USA: Unwin Paperback, 1984) p. 37

AJIS : Academic Journal of Islamic Studies vol. 3, no. 1, 2018

IAIN Curup - Bengkulu | p-ISSN 2580-3174, e-ISSN 2580-3190

Available online: http://journal.staincurup.ac.id/index.php/AJIS 
a variety of Muslim civilization among one region with other different regions. All three are the basic potential for the formation of the behavior and patterns of civilization, three things are; first, ethnic and racial characteristic. Second, the historical experience and awareness factors (the common historical experience and the type of awareness of a certain community passeses of the past) and the third, the demographic and geographical characteristic.

The first factor of ethnic and human race, usually has a major influence on the formation of the character of language and literature, writing, art style, various forms of jewelry, clothing, architecture, music, food and so on. The various external identities, seemingly more prominent are determined by this one factor. In connection with Islam AlJabiri mentions the ethnic and racial characteristics of Islam. ${ }^{3}$

The second factor of historical experience is seen as having a powerful influence in distinguishing the color of Islam in every region, not only as a cultural identity-maker, but also in establishing local cultural patterns. The similarity of historical experience can be the similarity of experiencing a certain pre-Islamic culture. ${ }^{4}$ According to Lewis the similarity of historical experience can also be a common experience of Islamization. ${ }^{5}$ Most of the people living in central, north africa, and indian have a relatively similar history of Islamization through military expansion and others such as Southeast Asia through trade and Sufi characters and their tarekat. ${ }^{6}$

While the third factor of population and natural environment, those are often very decisive in forming waves or accumulators that bring the flow of change is different from one region to another. The dynamics of politics, economics and other contemporary situations are usually played by this factor. Can be distinguished how the conditions of steppe region, desert, mountains, islands, coastal, hinterland, city, village, and so on, all have contributed greatly in the formation of different mentality to the inhabitants. According to Nasr geographical terms have caused some Muslim societies to be isolated and surrendered to certain natural conditions, such as those living in mountainous areas, on the contrary the

\footnotetext{
${ }^{3}$ See: Muhammad 'Abid Al-Jabiri, At-Turrathwa al-Hadarah :DirasahwaMunaqashah, (Beirut: al-Markazath-Thaqafi al-'Arabi, tt), p. 222

${ }^{4}$ SeyyedHussain Nasr, Islam in The Word: Cultur Diversity Within Spiritual Unity" dalamCultur, 1977, Volume IV, Nomor 1

5 Bernard Lewis, "TentangPeradabanIslam" dalamUlumul Qur'an. (Jakarta: YayasanParamadinan, 1989), Nomor 1, April-Juni

${ }^{6}$ M. A FatahSantoso "Agama danKeragamanKebudayaan :PerspektifPeradabanIslam" dalam Zakiyuddin Baidhawi dan Mutaharun Jinan (ed) Agama Dalam Pluralitas Budaya Lokal, p. 51.
} 
geographical terms which led to some others are very open, as they are at the crossroads of trade routes or the expansion of the military that being them as part of one particular type of Islamic culture. ${ }^{7}$

\section{Interaction of Islamic Values with Local Cultural Values}

The conceptualized framework is methodologically used in view of the relationship of Islam to the local culture of the reality of Islamic idealism and the reality of Islam. Islamic idealism is a permanent Islam sourced from revelation and al-sunnah have an absolute truth that theologically must be fully believed. In Islam the ideal of the concept of reality has been arranged and given its guidance from the official source of Islamic teachings namely al-qur'an and an explanation of its technical guidance in al-sunnah. ${ }^{8}$ The form of religious rituals in the life cycle and accommodation of external elements not found in the two official sources are considered to be unofficial or unjustified.

While religion (Islam) as a social reality is not only seen as a theological phenomenon containing the content of doctrine that comes from revelation in the form of teachings that have absolute truth. But religion (Islam) can be seen as a social-cultural phenomenon that constitutes culture as reflection and implementation of theological consciousness. Religion as a social institution or as a set of symbols used in social life is a doctrine residing in the sacred domain confirmed by revelation. ${ }^{9}$

While Islam as a reality of culture is in the domain of profane loading system of Islamic values contained in a number of distinct cultural values, with varied variants, in which Islam as a doctrine become the source of the formation of traditions in a particular community. ${ }^{10}$ Islam is not only

\footnotetext{
7 Nasr, Islam in The World; Culture Diversity Within Spritual Unity "dalam Culture, 1977, Volume IV, Nomor 1.

8Paryanto, Islam, Akomodasi Budaya dan Poskolonial, dalam Zakiyuddin dan Jinan (ed) Islam dalam Pluralitas Budaya, p. 64

9 Parsudi Suparlan, Kebudayaan Masyarakat Agama; Agama sebagai sasaran penelitian Antropologi' dalam Pasudi Suparlan (Ed) Pengetahuan Budaya, Ilmu-ilmusosial dan Pengkajian masalah-Masalah Agama, (Jakarta: Badan Litbang Departemen Agama, 1982), p. 3

10 Islam as identity and reality can also be expressed that Islam is a universal religion in doctrine or belief, but it can be very varied in the execution of its values in daily life called Islamic teachings and Islamic history. Islam as a teaching refers to beliefs and rarely derived from the holy book of the Qur'an and the Sunnah of the Apostles, whereas the history of Islam refers to the practice of various teachings in various Islamic geographies. See for example Kuntowijoyo, Islamic Paradigm Framework for Interpretation, Bandung, Mizan, 1989, Taufik Abdullah, History and Society: The Historical Trajectory of Islam in Indonesia, (Jakarta: Yayasan Obor Foundation, 1987)
} 
a religion, but also a community (people) who have their own understanding of revelation.

Islam is not a religion that is solely embraced individually, but collectively, which has consciousness, structure and collective action. On this plain Islam is confronted with the cultural reality (custom) of the Muslim community. Because religion (Islam) is a unique order which has two basic values that are metaphysical and skularistic. Both of these aspects contain elements of openness to engage in dialogue for the benefit of society in social life. ${ }^{11}$ The realistic approach seeks to bring together the religious substance dimension with the socio-cultural context of its adherents. According to Islam as a universal revelation religion needs to be present and reveal dri realistically in the diversity that colored the cultural social situation of his people. ${ }^{12}$

In the context of the application of the law of al-Maraghi and Rashid Ridho as quoted Syadzali said the law was enacted to fulfill human interests, the interests are relatively different because of the different time and place. ${ }^{13}$ This shows that laws are created for the benefit of humanity living in diverse locality. Therefore, in running the law does not have to be rigid and normative.

Kuntowijoyo states, religion or divine understanding should be seen as the frame of reference of the culture. According to him two ways to understand divinity. First; divinity in the theoretical sense; knowledge of the highest that gives rise to offerings. In this understanding there is no conformity between the sacred and the profane. Second; existential understanding of divinity. ${ }^{14}$ God is perceived as the ultimate goal that gave birth to the actualization. In everyday life, Muslims actualize their awareness of god in their behavior, so there is no duality between the sacred and the profane.

Religion as a cultural reality is a manifestation of the configuration of the religious spirit. This existential understanding brought religion into a humanitarian struggle. Because religion has a sacred symbol that embodies in a society tradition known as a religious tradition. ${ }^{15}$ Religious tradition is a collection or result of development throughout history,

\footnotetext{
11 Arief Mudatsir, 1998:15, Agama dalam Realitas Sosial Masyarakat, dalam Al-Fatah, (Palembang: IAIN Raden Fatah Palembang, 1995), Volume 2, nomor 1

12 M. Syafi'I Anwar, Pemikiran dan Aksi Islam Indonesia: Sebuah Kajian Politik Tentang Cendikiawan Muslim Orde Baru, (Jakarta: Paramadina, 1995), p. 182

13 Munawir Syadzali, Islam dan Tata Negara, (Jakarta: Rajawali Press, 1994), p.7

14 Zakiyuddin Baidhawu dan Mutaharun Jinan (Ed) Agama dan Pluralitas (ed) 20013,p.2

15See: NurSyam, Islam Pesisir, p. 17
} 
there are new elements that enter and some are left behind. ${ }^{16}$ One such struggle is how humans appreciate their religious teachings when dealing with local cultural values that become their beliefs. The presence of religion in social reality is tied to the locality of culture that is relative to the particular fan, and even at the beginning of its growth all religions tend to be communal. ${ }^{17}$ The truth doctrine that comes from god is perennial and transhistorical when it comes to humans must go through span of place and time, ${ }^{18}$ so that the diversity of religious appreciation is unlikely to be denied.

Someone religious beliefs pervade all aspects of his personality and significantly affect all his actions. Recognizing this is logical and ulturistic, that religious expression and articulation never have a single face. Islam has a standard of teaching that is believed to be absolute, but at the level of interpretation, beliefs and traditions are found to be diverse. The building of Islamic teachings that have come to us has mixed with historical construction and the construction of interpretation, so there are various schools of thought and color of cultural locality. The question is how it can happen, where religion is an eternal and absolute truth revealed through revelation to the prophet can be seen as a culture and social order or a set of symbols to communicate and social life ...?.

The answer to this question according to Suparlan ${ }^{19}$ lies in the methodological approach. It is true that religion has been handed down to mankind through who has been entrusted with God to teach the doctrines covered by that religion. But the problem is that we become religious people through the process of cultural transmission that is through experience and learning instructionally in social life.

Religion is believed to be obtained through others. This means that what is known about the religion is the result of the learning process and

\footnotetext{
16 Karel A. Steenbrink, Indonesia Pasca Reformasi: Angin Segar Bagi Agama Rakyat" dalam Bisnis, (Jakarta: Harian Bisnis Indonesia, Nomor 11-12, Tahunke 48, NovemberDesember, 2000), p. 42

17 See: Taufik Abdullah, Islam dan Pembentukan tradisi di Asia Tenggara: Sebuah Perspektif Perbandingan dalam Taufik Abdullah dan Sharon Siddiq (Ed) Tradisi dan Kebangkitan Islam di Asia Tenggara, (Jakarta: LP3ES, 1989), p. 58-99

18 This statement is inspired from Gestalt's theory of universality and particularity, in which Islam as the universal revelation that is present and accepted on earth whose dissemination and acceptance by humankind is enclosed in layers of local culture, so that universal Islam can only be grasped its meaning while in the hands of man, the actualization becomes a culture. See: Baidhow and Jinan, Religion and Cultural Plurality. 3-4

19 Parsudi Suparlan, Kebudayaan Masyarakat Agama; Agama sebagai sasaran penelitian Antropologi', dalam Pasudi Suparlan (Ed.), Pengetahuan Budaya, IlmuIlmuSosial, p 3
} 
experience it gained from relationships with others. ${ }^{20}$ Geertz in Suparlan says religion as a symbolic system that acts to solidify moods and motivations strongly, thoroughly and persistently in human beings by formulating generalized conceptions of law or order concerning existence (human) and enveloped these conceptions with a certain rule that reflects reality, so that the feelings of those motivations seem to be unique (uniquely) are real. ${ }^{21}$

Referring to the words used by al-qur'an in explaining man with lafadz bashar and insan. It is denoted that man in his position as bashar (whose outer dimension) possesses the innate nature by which he performs a function as' abd (servant of Allah) submissive, obedient, bound to responsibility to the sunatullah. His position as a human being (with a dimension of the spirit) has a mind by which doing the caliph function has the freedom to do and be creative. ${ }^{22}$ The realization of the function 'abd in belief and worship (religious), while the realization of the function of the caliph is to create a culture, therefore Islam is revealed to humans, while humans bear the mandate to carry out the functions of ' $a d b$ and functions of caliph, so that when the functions are realized, islam is a religion as well as a culture. ${ }^{23}$

Normative Islamic teachings that can reflect customary teachings in the context of acculturation of Islam with local culture or how Islamic appreciation of local culture. While the religion is embraced and carried out by humans during that time, religion can not be separated from the sociological and anthropological context of its adherents who are submissive and obedient to the dynamics process. ${ }^{24}$ Because Islam is very appreciative of dynamism included in the tradition. In understanding Islam including its traditions (read the hadiths of the prophet and the legacy of the 'ulama' salaf) must be dynamic. Tradition should not be an

20 Parsudi Suparlan, Kebudayaan Masyarakat Agama; Agama sebagai Sasaran Penelitian Antropologi, Makalah Pada Pelatihan Penelitian Agama Departemen Agama RI Jakarta, 14 september 1981, (Jakarta: Ikatan Kekerabatan Antropologi FSUI, 1982), p.3.

21 Clifford Geertz, Kebudayaan Masyarakat Agama: Agama sebagai Sasaran Penelitian Antropologi, dalam PasudiSuparlan (Ed) Pengetahuan Budaya, Ilmu-IlmuSosial Dan Pengkajian Masalah-Masalah Agama, (Jakarta: Badan Litbang Departemen Agama, 1982), p. 21.

22 Musa Asy'arie, Manusia Membentuk Kebudayaan dalam Al-Qur'an, (Yogyakarta: lembaga Studi Agama dan Filsafat, 1992), p. 113.

${ }^{23}$ Santoso, Agama dan Keragaman Kebudayaan; Persepktif Peradaban Islam' dalam Zakiyuddin Baidhawi dan Mutaharun Jinan (ed) Agama dalam Pluralitas BudayaLokal, hal, 47.

24 See: Paryanto, Islam, Akomodasi Budaya dan Poskolonial, dalam Baidhowi dan Jinan (Ed) Islam Dalam Pluralitas, p,66. 
idol of thought, but must be developed and expanded in accordance with space and time. ${ }^{25}$

The touch of Islam with local culture can be interpreted and traced through the process of acculturation in a dialectical way. Because Islam as a social reality is not only seen as a theological phenomenon containing doctrine in the form of teachings that have absolute truth. But Islam is seen as a sociocultural phenomenon that shapes culture as a reflection and implementation of theological consciousness. ${ }^{26}$ Islam as a cultural reality contains a system of Islamic values contained in a number of distinct cultural values with diverse variants. Because Islam as a doctrine becomes the source of radical formation within a particular community. ${ }^{27}$ How the interaction of Islam with local culture is acculturative using the concepts of assimilation, accommodation, conflict and integration in life cycle rituals can be done, is the next discussion.

\section{Assimilation of Islamic Values With Local Culture}

One of the conceptual frameworks used in the study of Islamic relations with local culture are some concepts that can describe the interaction of Islam as a value system with the local culture as a value system on the other side of the social development process. Islam and local culture in social life are shared values and their dynamics depend on the behavior of their citizens in addressing the issue of life. The interaction of Islam with the local culture in this study focused on the family life cycle ceremony.

The family in the process of social life can be seen from two sides of the social structure and the side of social institutions. Social structures are rules that serve as the basis for action models. Pranata from the side

${ }^{25}$ Muhammad Syahrur, al-Kitabwa-Alqur'an: Qira'ahMu'assirah, (Damascus: al-Ahali li Aththba'ahwa an-Nasyrwa Tauzi, 1992), p. 33-34.

26 Parsudi Suparlan, Kebudayaan Masyarakat Agama; Agama sebagai sasaran Penelitian Antropologi, dalam Parsudi Suparlan (Ed) Pengetahuan Budaya, Ilmu-ilmu Sosial dan Pengkajian Masalah-Masalah Agama, (Jakarta: Badan Litbang Departemen Agama, 1982), p 3.

${ }^{27}$ Islam as identity and reality can also be expressed that Islam is a universal religion in doctrine or belief, but can be very varied in the implementation of its values in daily life called Islamic teachings and historical Islam. Islam as a teaching refers to the beliefs and rarely derived from the holy book of the Qur'an and the Sunnah of the Apostles, whereas historical Islam refers to the implementation of the teachings that vary in various Islamic geographies. See for example Kuntowijoyo, Islamic Paradigm Framework for Interpretation, Bandung, Mizan , 1989, Taufik Abdullah, History and Society: Islamic Historical Trajectory in Indonesia, (Jakarta: YayasanObor Foundation, 1987 
of the function is an effort in fulfilling the family in a fundamental way. ${ }^{28}$ Relation of family to religion is always through ceremony, which is its structure. Because there is no relationship that going with god but through the structure. Structure serves as a container of social values interaction framework. Various forms of social interaction based on values are characterized by the ongoing contact and communication is an important aspect in knowing the behavior that will be executed in the face of changes in social relationships. ${ }^{29}$

In social relations Robert E Park ${ }^{30}$ presents four important concepts, namely; competition, conflict, accommodation and assimilation. In relation to the interaction of Islam with local culture in the family life cycle ritual the three latter concepts of conflict, accommodation, and assimilation are used in analyzing the problem. These three concepts are not explained partially or separately, but thoroughly, because they are related to each other and are even related to other concepts.

Assimilation is one form of social process associated with the process and the outcome of the meeting of two or more cultures. ${ }^{31}$ Assimilation as a social process can occur when there are three things: first; human communities with different cultural backgrounds. Second; intercourse intensively for a long time, and third; the cultures of the community each experience a change of character with certain characteristics and its elements change into a mixed culture. ${ }^{32}$

The continuity of these three factors against the background of Islamic culture on the one hand and local culture on the other hand, interact intensively in a relatively long time. The consequence created changes in the form and nature of both cultures (Islam and local culture) that eventually gave birth to a mixed culture in a peculiar form called the local Islamic culture.

Gordon writes that matters relating to assimilation are the majority and some minorities. ${ }^{33}$ That is the supporters of Islamic culture with local

28 Suparlan, Kebudayaan, Masyarakat dan Agama, (Jakarta: Ikatan Kekerabatan Antropologi Fakultas Sastra Universitas Indonesia (FSUI), 1982), p, 33.

29 Hari Purwanto, Orang Cina Khek dari Singkawang, (Depok: Komunitas Bambu, 2005), p, 12.

30 Adam Kuper and Jessica Kuper, (edited) Encyiclopaedia of the Social Sciences, (London and Newyork: Second Eddition. RoutledgeTailor and Prancis Grouf, 2001), 403

31 Hari Purwanto, Kebudayaan dan Lingkungan dalam Perspektif Antropologi, (Yogyakarta: Pustaka Pelajar, 2000) p. 116.

32 Koentjaraningrat, Pengantar Ilmu Antropologi, AksaraBaru, (Jakarta: Cetakan VII, 1989), hal, 255

33Milton M. Gordon, Assimilation in American Life:The Role of Race Religion an and National Origin, (New York: Oxford University Press, 1964), p. 61 
cultural support groups. One of these classes belongs to a minority, usually will change the characteristic nature of the elements of culture and adapt to the majority of the majority of cultures and enter into the majority culture. ${ }^{34}$ If the Islamic culture is superior and the majority of the local culture, then the Islamic culture more coloring local culture, so will form a typical culture of Islam. Likewise, it happens.

Gordon further argues ${ }^{35}$ that the term assimilation is more often used by sociologists, whereas anthropologists prefer to use the term acculturation. Although both terms contain the same meaning, they can also show different dimensions. Bert E Park and Ernest W Burgess ${ }^{36}$ as sociologists give understanding and limits of assimilation is a process of fusion of members of a society or a group gets the impression, feelings, and attitudes of other people or groups, sharing history and experience united in a more general cultural life.

Some anthropologists such as Robert Renfield, Ralp Linton and Melville Herskovit understand the symptoms obtained when groups and individuals of different cultures come into direct contact with changes occurring within the realm of indigenous cultures of each of these groups or other groups .37

The two limitations of sociologists and anthropologists contain an understanding of the occurrence of people's encounters or cultural behaviors, which competitively affect and eventually the culture of both undergoes a change of form. The difference is only seen with the absence of structural features in acculturation restrictions. While in the assimilation of the assimilation of socio-structural relationship is reflected from the sharing of experience between them and assimilation in the wider cultural life. ${ }^{38}$

The explanation illustrates the occurrence of a meeting of cultural behavior, which resulted in both sides affecting each other and eventually

34 There is also a mention of a majority and a minority with deeper cultural links with strong cultural credentials or their weaknesses (or, according to the ability of the citizens of cultures of other cultures, are the Africans and Africans and the Negro Bantu, the dominance of the extremists into the membership of the second supporting society). Examples of the dominance of extremes in the case of community members in favor of cultural entities may be able to bring members of other supporting societies into their inactivity with lower status positions and excommunication from high status positions and at the same time that the participation of other supporting societies in such a high status position. Seelauer, Perspective About Changes, p. 405

35 Milton M.Gordon, Assimilation in AmericanLife ,p. 61.

${ }^{36}$ American Anthropologist, Volume 38 Nomor 1, p. 149.

${ }^{37}$ See: American Anthropologist, p, 149.

38See: Purwanto, Kebudayaan dan Lingkungan, p. 117. 
the two cultures changed shape. The difference between the two concepts where in the limitation of assimilation found a socio-structural relationship. While on the limitation of acculturation there are no structural features that are reflected in sharing their experience and incorporated with them in a commom cultural life. ${ }^{39}$

Further Herskovits ${ }^{40}$ the meaning contained in acculturation is different from cultural change. Acculturation is only one aspect of cultural change, while cultural change is one of the stages of assimilation. In addition, acculturation differs from diffusion. Herskovits mentions such diffusion differences with the achieved cultural transmission. ${ }^{41}$ While acculturation with cultural transmission in process. All forms of acculturation imply that understanding, especially in contexts without any contact from those who advocate certain cultures. Because acculturation refers to the influence of one culture to another culture or the interplay between two cultures that result in cultural change.

Acculturation involves various changes in culture caused by the influence of other cultures. Ultimately, there is an increasing number of similarities in the culture. The influence is reciprocal, stronger on one side only. In relation to diffusion, acculturation has more influence than diffusion, at least in the sense that other cultures are influenced more like the culture that influences it. ${ }^{42}$ In this connection Kroeber argues that "acculturation as a process of cultural change has increased the similarity between two cultures". 43 While diffusion is a more micro-idea and most of the diffusion studies focus on the special elements of culture.

The acculturation process shows results although it can also show as a condition. Acculturation must be distinguished by assimilation, since assimilation is the time phase of an acculturation. ${ }^{44}$ The question is whether in general assimilation can be a form of acculturation? from the perspective of consistency and clarity as well as the frequency of use of acculturation references more indicate individual aspects than groups, it appears that the two concepts have ambiguous meanings. In this connection Herskovit argues that acculturation should be regarded as $a$ two-way process or interplay between two interrelated groups. ${ }^{45}$

${ }^{39}$ Melville Herskovits, Acculturation: The Study of Culture Contact, (New York: Feter Smith, 1958), p. 10

${ }^{40}$ Herskovits, Acculturation; The Study of Culture, p.10

${ }^{41}$ See: Harsojo, Pengantar Antropologi, $p .164$.

42 Harsojo, Pengantar Antropologi, p. 164.

43 Kroeber dalam Lauer, Perspektif tentang Perubahan, p, 403.

${ }^{44}$ Herskovits, Acculturation; The Study, p, 10.

${ }^{45}$ Herskovits, Acculturation; The Study, p, 10. 
Arnold M Rose ${ }^{46}$ assimilation is a complete adoption of the culture of other social groups that eventually a person or group no longer have characteristics that can identify themselves with the culture of its predecessor. In addition, he no longer has a certain loyalty to the culture of his predecessor or a process that leads to adoption (new culture). While acculturation is the cultural adoption of other social groups by individuals or groups. It further refers to adoption as a characteristic of assimilation. Their loyalty to the original culture is getting smaller and eventually the group identifies itself into a new culture.

The opinion of Rose is in accordance with Park and Burgess's restrictions that assimilate judgment is the perfect end product of a social contact. Furthermore Park and Burgess ${ }^{47}$ argue social contact as the beginning of interaction, assimilation is the end product. Basically social contact is a fraud in the process. Usually assimilation picks up quickly where the main contact exists, ie where there are frequent connections, such as in the touch relationship area, in the family and in fun groups. Secondary contacts facilitate accommodation, but can not increase assimilation on a large scale.

In subsequent developments assimilation is associated with varied variables, as Gordon ${ }^{48}$ finds seven variables associated with assimilation, ie; (a) cultural or behavioral assimilation (commonly called acculturation) in the form of changes in cultural patterns towards adaptation to the culture of the majority group (b) cultural assimilation, that is, on a large scale they belong to various groups, cliques and institutional groups of the majority, the fundamental level (c). Assimilation of marriage or amalgamation, that is, the occurrence of mixed marriages on a large scale (d). Assimilation of identification, namely the development of feelings as a nation as belonging to the major group (e). Assimilation is reflected in attitudes (attitude receptional assimilation) which does not allow for the emergence of prejudice (f). Behavioral assimilation is behaviour receptional assimilation in the form of absence of discrimination (g). Citizenship assimilation is manifested in the absence of value conflict and power conflict.

Various variables according to Gordon assimilation requires that the culture that comes later to adjust to the cultural group that was visited. Majority group culture can be used as a measure to assess individual or group success as they adapt. Gordon boundaries can be used to analyze the occurrence of assimilation between Islamic culture and local culture

\footnotetext{
46 Arnold M Rose, Encyiclopedia of the Social Sciences, (tt, tp, 1956),p 557-558.

47 Purwanto, KebudayaandanLingkungan, p.118.

48 Milton M Gordon, Assimilation in American Life, (USA, 1964), p, 27
} 
in a particular group. In analyzing the meeting of Islamic culture with local culture involving the socio-cultural relations of both cultures, because in it there is sharing of experience and unification in the context of cultural life.

The unit of analysis in this study is the family as an institution ${ }^{49}$ supporting the culture of Islam and local culture, because families mediate the spread of culture to other families. Bernert mentions that in the analysis of individual or family acculturation is not the main target, although individuals or families can change their behavioral habits and beliefs, because of the influence of foreign habits and beliefs, but adat (culture) in that society is acculturated..$^{50}$

In addition to acculturation in the form of assimilation of Islamic values with local culture with the characteristics of Islam as a cultural reality that contains the system of Islamic values contained in a number of cultural values, then the concept of accommodation of Islamic interaction with local culture in the ritual cycle of life can also be done .

\section{Accommodation Islamic Values with Local Culture}

One of the concepts used in analyzing Islamic Islam relationships with local traditions is the concept of accommodation. Understanding the interaction of a value system with another value system in a social process, the concept of accommodation is related to the concept of assimilation. Ernest $\mathrm{W}$ Burgess ${ }^{51}$ argues that accommodation is a process of social adjustment to a (better) situation by maintaining a social distance between groups and communities that do not generate conflict.

But he says accommodation can not always create assimilation, especially if there is no intensive and deep contact. Baldwin ${ }^{52}$ claimed the collapse of old habits and new habits. In such a process during which the adjustment takes place, various conflicts are avoided and old habits are sought, altered and adapted, so that the involved cultural supporters get something different or something new.

\footnotetext{
49 The institute in the structure of the social society can be seen from its function and its function; function as a network, ie; reproduction, sex, education and others.As for social structures; father, mother, son- right and obligation -distribution-rule-norm. SeeParsudiSuparlan, Culture, Society and Religion, p. 13. In the context of audiences, the two are seen in the two respects of the relationship as being related to the life cycle ceremony.

50 Bernet dalam Lauer, Perspektif Tentang Perubahan, p, 403.

51 Ernest W Burgess, Encyiclopedia of the Social Sciences, (tt, tp, 1957), p. 404.

52 Baldwin, Dictionary of Sociology, 1957, p. 403.
} 
Accommodation means accommodating, adjusting, matching, reconciling, gentle, kind and helpful. ${ }^{53}$ In addition, accommodation can also be understood as a meaningless restriction not totally without change. The deeper understanding and limits of accommodation of any social process, whether consciously or unconsciously contained in the changing functional relationships between personality and groups are avoided, eliminating conflicts and adjusting reciprocally with the proviso that behavioral patterns altered based on social learning are not top biological derivatives; and the social relationships resulting from this process, the most frequently mentioned variations (or methods) of accommodation are arbitration, compromise, consensus, conversion, subordinate service, and tolerance. ${ }^{54}$

Accommodation on the one hand indicates a process, while on the other hand indicates a situation. As a process characterized by the effort to create balance, as well as to avoid the things that cause conflict. ${ }^{55}$ Even if the business is done consciously or done in a forced way. As a condition, accommodation is characterized by the creation of a balance of relationships between individuals and groups. Thus accommodation is formed through arbitration, compromise, conciliation, conversi, subordination, and tolerance. In relation to religious values and the local cultural values of accommodation is interpreted as a situation can be a compromise, consilation, subordination, and tolerance.

Relation to Islamic values as a system of life whose totality is exclusive and inclusive approach akomodaitf-reformative, conditional and affresiatif. ${ }^{56}$ Can be used in the interaction of Islam with local culture. This approach is an approach that better captures the Islamic moral idea than its formal legal aspect. Islamic values are conceived in a contextual, lithe, replicative and appreciative way to the local culture. Text hegemony laden with Arab cultural hegemony can be avoided ${ }^{57}$. This model of thought is in line with the thoughts of Syharur ${ }^{58}$ and Fazlur Rahman. ${ }^{59}$ Understanding and implementing Islamic teachings in any region does not have to be the same as the Arabian culture in which Islam is revealed. When Islam enters in certain areas there will be adjustment, attraction or

53 See: Jhon M. Echols et.al, KamusInggris Indonesia, (Jakarta: Gramedia, 1987), p. 6

${ }^{54}$ Hornell Hart, Dictionary of Sociology, (tt, tp, 1944), p. 2

55 See; Purwanto, Orang Cina Khek, p. 16.

56 Jandra, Islam Dalam Kontek Budaya dan Tradisi Plural" dalam Baidhowi dan Jinan (Ed) Agama dan Pluralitas, p. 72.

${ }^{57}$ See: Jandra, Islam Dalam Kontek Budaya dan Tradisi Plural" dalam Baidhowi dan Jinan (Ed) Agama dan Pluralitas, p. 7.

58 Muhammad Syahrur, al-Kitabwa al-Qur'an : Qira'ahMu'asirrah, (Damaskus: al-Ahali li ath-Tiba'ahwa at-Tauzi, 1992)

59 Fazlur Rahman, Membuka Pintu Ijtihad, (Bandung: Pustaka Al-husna, 1984) 
struggle with local traditions. Understanding of religion and culture should be seen as a dialectical and accommodative process. Islam in accordance with the nature of its universality must reveal its cultural values, self-tame, friendly in the face of community life. ${ }^{60} \mathrm{By}$ this nature Islam can accommodate with local culture, vice versa.

The changes and dynamics of culture in space and time confront the religious community on the collective consciousness that the structural and cultural adjustment of religious understanding is a necessity. ${ }^{61}$ It is not to drag the religion to subordinate position in relation to the dynamics of socio-cultural, even political and economic development ${ }^{62}$. It is therefore necessary to examine the elements that can unite the culture and foster consciousness of cultural unity. ${ }^{63}$

In dialectical process, there is the possibility that Islam can color, alter, process and modify the local culture. However, it does not close the possibility that it will happen that Islam is colored by various local cultures. This situation depends on the support of active Islamic values or the support of local cultures who have understood Islam according to their local cultural heritage. In the context of Islam and local culture can give birth to the process of localization or the formation of elements of Islam that will give birth to local Islam, or otherwise the Islamization of local culture gave birth to local Islam.

Accommodations differ with adaptation, even though the two concepts are a form of adjustment. The adapt concept is more often used in studying structural changes based on variability and biological selection. ${ }^{64}$ Adaptation can also point to the necessity of a social system to deal with its environment. First,there must be an adjustment of the social system to the irreducible demand of the reality coming from the environment; second, there is an active process of transformation from that situation. Instead of accommodation is closely related to functional changes, such as changes in habits and customs of a society in social processes. ${ }^{65}$ In this study the form of compromise and conversion are two

60 Jandra, Islam Dalam Kontek Budaya dan Tradisi Plural" dalam Baidhowi dan Jinan (Ed) Agama dan Pluralitas, p. 77.

${ }^{61}$ See: Jandra, Islam Dalam Kontek Budaya dan Tradisi Plural" dalam Baidhowi dan Jinan (Ed) Agama dan Pluralitas, p. 73.

62 Bahtiar Effendi, 'Masyarakat Agama dan Tantangan GloBalisasi: Mempertimbangkan konsep depripatisasi Agama", dalam Ulumul Qur'an. (Jakarta: Yayasan Paramadina, Nomor 3, 1997), p. 43.

63 Rolan Robertson, Sociology of Religion, Diterjemahkan oleh Achmad, Agama dalam Analisa dan Interpretasi Sosiologis, (Jakarta: Rajawali Press, 1988),p. 220.

${ }_{64}$ Purwanto, Orang Cina Khek, p. 17

65 Purwanto, Orang Cina Khek, p. 17 
concepts that can be used in analyzing the relationship of Islam with local culture in social relationships that have been formed in long time.

Accommodation that refers to any process that refers to the state, is closely related to the concept of compromise and the concept of conversion. Lumley ${ }^{66}$ mentions an agreement reached by mutual giving / gifts; the conciliation process consisting of the exchange of values to arrive at the celebrations becomes more or less satisfactory. At least many of them feel satisfied than the exchange before. Because in realizing assimilation, there will be a granting of certain values of Islamic values to the values of local tradition and so on.

Accommodation in the form of compromise is often unable to satisfy both sides of the culture, because the two cultures have different arguments and views, so the relationship between the two cultures can not run intensively. Another form of accommodation that is expected to play a role in overcoming those relationships in realizing assimilation is conversion. Conversion can be used as a guide or direction in realizing assimilation, so that potential sources of conflict can be eliminated. ${ }^{67}$

The tendency towards conversion is characterized by the appearance of ambiguity and the occurrence of change in one or several elements of culture. Such changes may occur voluntarily or otherwise. Conversion accommodation emphasizes the importance of adopting patterns and ethos from out grouf voluntarily, through personality adjustments. When this happens the ambiguity is diminished or lost and ultimately in grouf is thoroughly involved in the out grouf culture. Their old attitudes and value systems have been replaced by new attitudes and value systems.

Accommodation is also associated with integration. Integration is a generic term and has considerable meaning. Integration according to Waston $^{68}$ social process which aims to harmonize and unify the differences of opposing elements, whether these elements are elements of personality, individuals, or groups of larger groups of society. 69 Schermerhorn argues in examining the concept of integration should be associated with various elements of society's community system. The socio-cultural and political aspects covered in the concept of integration must be considered. Schermorn's concept of integration is used in analyzing the relationship of Islam with local culture in a community. Integration according to him is a process in which elements or units of

\footnotetext{
${ }^{66}$ Fredrich E Lumley, Dictionary of Sociology, (tt, tp,194)p. 55

67 Purwanto, Orang CinaKhek, p. 17

68 Waston, Dictionary of Sociology, p. 159

${ }^{69}$ Lumley, Dictionary of Sociology, 1954, p. 159
} 
society are used to perform activities and coordinated to achieve the goals and activities of sustainable dominant group. ${ }^{70}$

This view is in line with what K.W. Deutsch $(1975,5)$ is quoted by Koentjaraningrat, ${ }^{71}$ where in examining the conception of integration should not only emphasize the political aspect alone, but also on the socio-cultural aspects contained therein. Koentjaraningrat differentiates between the integration of elements of culture (kinship and relegi) and the integration of cultural components (ideology, behavior, and sharing of physical manifestations). In essence cultural integration is more referring to the form of integration of various cultural elements. The existence of cultural interaction is configuration or thematic integration. ${ }^{72}$ Various elements of culture that is integrated in a culture, still maintain its identity.

This view of Schemerhorn suggests that integration does not constitute or represent a fixed state, but rather it refers to a changing state. The integration according to him tends to be dynamic, not to show the utmost to a permanent, but situational one. ${ }^{73}$ This state of affairs is characteristic of a dynamic culture in situational both within the supportive community of Islamic culture and the local cultural support community..

The concept of Schermerhorn integration can explain three problems, first; integration as a matter closely related to legitimacy; second; integration as a matter closely linked to cultural concurrency and, third; integration as a problem that creates a mismatch of views, especially in connection with the integration of a culture of a sub-culture society. ${ }^{74}$ Some of these concepts are used to analyze the interaction of Islam with local culture in a situational of two communities supporting the Islamic culture with local cultural communities. In situational it occurs the accommodation of various cultural values of the two cultural values.

Acculturation can occur in two processes, first: (a) a process of acculturation of a person by voluntarily adopting an external form and ethos, and / or (b) a process of adjusting to something different, characteristic behavior or loss of enthusiasm individualization in general, agree on patterns that are respected and recognized by society as a whole

\footnotetext{
70 Schehermerhorn, Comparative Ethnic Relation Framework for Theory and Research, (New York: Random Hous, 1970), p. 66

${ }^{71}$ Koentjaraningrat, Diversity and Variety Ethnic Diversity and National Integration in Indonesia, Makalah, (Jakarta: 1987), p. 60.

72 Koentjaraningrat, Diversity and Variety Ethnic, p.60.

73 Schehermerhorn, Comparative Ethnic Relation, p. 66.

74 Schehermerhorn, Comparative Ethnic Relation, p. 66
} 
at a particular time or time. second; a mechanism undertaken in the process of accommodation where, attitudes and value systems are abandoned by new attitudes and values accordingly accepted and made to serve as shared values and patterns of all activities or behaviors. ${ }^{75}$

Acculturation in the form of assimilation and accommodation of Islamic values with local culture takes place in various elements of Islam and local culture. Such acculturation can occur reciprocally in which Islam on the one hand colored predominantly local cultural values. And on the other hand local culture coloring Islamic values. But in addition to the form of acculturation, the interaction of Islam with local culture in the ritual of life cycle can be seen with the concept of conflict and integration of both. This issue is the next study. Because Islam in the relationship can reject local culture that is contrary to Islamic teachings, but at other times Islam must be able to tame themselves so create the accommodation.

\section{Conflict and Integration of Values of Islam and Local Culture}

The conflict and integration in this study are used in order to understand the tension or conflict between the Islamic value system and the local cultural value system. Conflict and integration is one form of social interaction. Form of social interaction in the form of cooperation, competition and even can be in the form of conflict. ${ }^{76}$ Conflict is defined as the process of achieving goals by weakening the opponent without regard to norms and values that apply. Others argue that conflict is a struggle between individuals or between groups to win a goal that want to be collected together. ${ }^{77}$ While integration is the unification of groups that were separated from each other by eliminating the social and cultural differences that existed before. ${ }^{78}$

According to Parsons, the most important factor in integration is the consensus between members of the public regarding certain values. in society there are always certain goals and principles that are considered absolutely true. the value system is a source of social integration and an element that stabilizes the socio-cultural system. ${ }^{79}$ Conflict and

75 Encyclopedia of Social Science, (tt, tp, 1957), p. 353

76 SeloSoemardjan dan Sulaiman Sumardi, Setangkai Bunga Sosiologi, (Jakarta: Yayasan Badan Penerbit Fakultas Ekonomi Universitas Indonesia, 1974), p. 177.

77 Parsudi Suparlan, Konflik Sosial dan Alternatif Pemecahannya" dalam Antropologi Indonesia, (Jakarta: Universitas Indonesia, Nomor 59, 1999) p.7

78 Saifuddin Ahmad Fedyani, Konfliks dan Integrasi: Perbedaan Paham dalam Agama Islam , (Jakarta: Rajawali Press, 1986),p. 7

79 Talcots Parsons dalam Nasikun, Sistem Sosial Indonesia, (Jakarta: Rajawali Press, 2000), p. 12. 
integration in this study are used simultaneously, because one concept is the opposite of the other.

Conflict and integration are focused on cultural conflicts or values of Islamic values and local cultural values. the conflict aims to defeat or eliminate certain values that the opposing group of Islamic support groups and other groups support the local culture in an Islamic community. it is assumed that when Islam comes to a society that has previously embraced a local cultural value system there can be tension between supporters of Islamic culture and local cultural advocates.

The conflict is a tension between eternal doctrine and its embodiment in individual and group life, which is a major factor in the spread of Islam. ${ }^{80}$ Islam's rejection of local culture will occur if local values are contrary to Islamic doctrine. The conflicts of Islam with local culture can embrace Islam to get symbols that are in harmony with the culture of the people who want to be incorporated into the Islamic community. ${ }^{81}$ Azra mentions the interaction of Islam with local culture in essence involves a fight or at least the tension between the Islamic doctrine that is believed to be absolute, because it comes from a god with local cultural values (customs) of human products that are often not in harmony with the divine teachings. ${ }^{82}$ As long as the attainment of the demand for the unity and purity of the true doctrine has not been achieved, it is also the struggle of Islam with the local culture.

Still according to Azra religion gives human a number of conceptions about the construction of reality based on divine authority. But this is not entirely applicable, since it is not uncommonly conceived by god through symbolism and ambiguity, thus giving rise to different interpretations, ultimately giving rise to extra tension that is difficult to avoid. ${ }^{83}$ While on the other hand the community builds its own humanitarian reality construction known as customs or traditions. Tension will be created when both forms of reality construction insist on maintaining their own existence. Instead the tension subsides when one party provides accommodation, whether forced or voluntary to the other party. ${ }^{84}$ Geertz discloses the causes of the conflict as "intrinsic ideological conflicts

80 Abdullah, Sejarah dan Masyarakat, p. 1

81 A.A Bagus Wirawan, "Akulturasi Islam-Hindu di Bali: Tinjauan Historis dalam Aswabmahasin (Ed), Ruh Islam dalam Budaya, p. 237.

82 Azra, "Interaksidan Akomodasi Islam dengan Budaya Melayu Kalimantan" dalam Mahasin (Ed) Ruh Islam Dalam Budaya,p. 184.

83 Azra, "Interaksi dan Akomodasi Islam dengan Budaya Melayu Kalimantan" dalam Mahasin (Ed) Ruh Islam Dalam Budaya, p. 184.

${ }^{84}$ Azra, "Interaksi dan Akomodasi Islam dengan Budaya Melayu Kalimantan" dalam Mahasin (Ed) Ruh Islam Dalam Budaya, p. 185. 
resting on deef-feels dislike for the values of other groups" 85 between supporters of Islamic culture and local cultural advocates.

In this condition, Islam has a dilemmatic position, one side must maintain its scripturalist nature with absolute doctrine, while on the other hand it must tame itself or bend to local culture. Abdullah mentions muballighs from the early days of the Islamization process in the northern coastal areas of Java island or also in some coastal areas of Bali in the 17th century did not impose Islamic teachings, rules and laws in totality. In the process Islam not only tamed its target, but also tamed itself. 86 So in certain circumstances Islam must allow interpretation that may be somewhat separated from the full and eternal revelation.

The relationship between Islam and Banjar Kalimantan culture finds that the master teachers (ulama in traditional groups) are actually expected to become actors upholding scripturalist Islam, proving to have a strong tendency to let local beliefs and Islamic practices in a very accommodating color. They tend to be objects of practices that are incompatible with the doctrine of scripturalist Islam. ${ }^{87}$

Azra found in his study of the interaction and accommodation of Islam with MelayuKalimantan culture explaining in the process of reciprocal accommodation between Islam and Malay culture, domestication occurred against Islam. This is difficult to be avoided because if Islam persists with its strict scripturalism, it will deal with the strong risestencies of established belief systems, cultures and local traditions. ${ }^{88}$ In such case, if Islam is difficult to enter the local cultural area. Accepting accommodation to some extent is therefore more acceptable to the local culture. ${ }^{89}$ This problem is what will be seen in this study by focusing on ritual aspects of life cycle in family institution.

\footnotetext{
85 Geertz, The Religion, p. 356.

${ }^{86}$ Abdullah, Sejarah dan Masyarakat,p. 3.

${ }^{87}$ AfandiDaud, Islam dan Masyarakat Banjar: Deskripsi dan Analisa Kebudayaan Banjar, Disertasi, (Jakarta: UIN Jakarta, 1980) p. 640-765.

${ }_{88}$ Azra, "Interaksi dan Akomodasi Islam dengan Budaya Melayu Kalimantan" dalam Mahasin (Ed) Ruh Islam Dalam Budaya, p. 192.

89 Another opinion says that the tensions are among the Islamists who are categorized as high tradition and Islam as low as Islam is popular as a low tradition. Yet even though it has a distinctly differentiated image in its very nature, it can often run alongside the juxtaposition, harmoniously and mildly. The conflicts of a state of affairs when the (high) Islam officially follows a well-defined or artificialification and condemnation against the popular or Islamic " in Baidhowi dan Jinan (Ed), Religion and Plurality Culture, p.64 faith. See: Paryanto, Islam "Accommodation Budaya dan Poskolonial.
} 
Accepting the concept of accommodation to some extent means that there has been a process of cultural integration. The concept of integration considers society to be basically integrated on the basis of the agreement of its members on certain social values, or a general agreement that has the power to overcome differences of opinion and interests among members of society. This integration approach views society as a system that is functionally integrated into an iquilibrium form. ${ }^{90}$ In the context of this study, integration is the unification of the values of one group (Islamic values) with the values of other groups (local cultural values) that form new values (local Islam).

The conflict approach in this study is directed towards conflict and integration in the value system as a guideline for community behavior. Coser mentions conflict is a dispute over values or demands regarding status and power. ${ }^{91}$ Following the Coser tension of Islamic values and local culture is a demand for the status of both Islamic and local culture. Because acording to Coser conflict can take place between individuals, groups or between individual and group. ${ }^{92}$

Phenomenal social conflict has occurred since the formation of a society. The formation of society gave rise to social relations. Which requires interaction between individuals, between individuals with groups and between groups with groups in social systems. The same thing happens to one value system with another value system in the society. The basic principle of conflict theory that every society contains inner conflicts, conflict is a symptom inherent in every society. Every element of society becomes a potential for conflict and social change. ${ }^{93}$

Conflict theory partially developed as a reaction to structural functionalism. Conflict is more concerned with disentigrated, whereas integration seeks a balance in people's lives. However, the opposition of both theories is not mutually rejecting, but complement each other. ${ }^{94}$ This approach is actually derived from the evolutionary theory that developed so long. ${ }^{95} \mathrm{An}$ organism has certain elements associated with an overall or totalism.

\footnotetext{
90 Nasikun, Sistem Sosial Indonesia, p. 9.

91 K.J Veeger, Realitas Sosial: Refleksi Filsafat Sosialatas Hubungan Individu Masyarakat dalam Cakrawala Sejarah Sosiologi (Jakarta: Gramedia, 1993). P. 211

92Veeger, Realitas Sosial, p. 211

93 Ralf Dahrendorf, Case and Class Conflict in Indutria Society, (California: Stanford University Press, 1959), p.162

94 Veeger, Realitas Sosial, p. 212

95 Herbet Spencer dalam Jusman Iskandar (ed) TeoriSosial, (Bandung: Program PascaSarjana UIN Sunan Gunung Jati, 1999), p. 399.
} 
The integration approach considers society to be essentially integrated on the basis of the word of its members toward the value of a certain jurisdiction, or a general agreement which has the power to overcome differences of opinion and interests among the members of society. The integration approach views society as a system that is functionally integrated into a form of equilibrium. ${ }^{96}$

Dahrendorf sees every society as subject to a change process. This theory understands disputes and conflicts within the social system. According to him various elements in society (including social and cultural values) contribute to disintegration and change. ${ }^{97}$ Conflict sees the regularity that exists within the society derives from coercion of its members by those above. Functionalism tends to see society informally bound by norms, values, and morals.

He considers people have two faces of conflict and consensus. The consensus hatus testing the value of integration in society and conflict should examine the conflict of interest and the use of violence that binds the common people in the face of pressure. Society will not exist without consensus and conflict being the requirements of each other. There will be no conflict without prior consensus. ${ }^{98}$

Pasons in his functional theory with the concept of social order will be formed to prevent the conflict between citizens of a society lies in the relationship among the cultural system, social, and personality. ${ }^{99}$ This situation leads to institutionalization of cultural values within the norms and rules of the social system. Members of society will be obedient, because the rules that exist harmoniously with the values that he embraced. If the values adopted form social norms and personality, people are in a stable state and there will be no conflict. ${ }^{100}$

Following the Parsons conflict will not happen if the values of life together fit the social and personal needs in an integrative way. The condition lies in the strong bonds of cultural systems, social systems and personality systems. ${ }^{101}$ Functionalism regards shared values as a unifying bond, whereas for conflict theory it is the creation of a dominant group or

\footnotetext{
96 Nasikun, Sistem Sosial, p. 9.

${ }^{97}$ George Ritzer dan Douglas J Goodman, Modern Sociological Theory, Terjemahan oleh Aliman, TeoriSosiologi Modern, (Surabaya: KencanaPrenada Media Group, Edisike-6 , 2004), p. 153.

98 George Ritzerdan Douglas J Goodman, Teor iSosiologi, p. 153-154.

99 Nasikun, Sistem Sosial, p. 14.

100 Soejono, Soekanto, Beberapa Teori Sosiologi tentang Struktur Masyarakat, (Jakarta: Rajawali, 1983), p. 256-257.

101Soejano Soekanto, Beberapa Teori Sosiologi, p. 256.
} 
class drama to impose values. ${ }^{102}$ This means that conflicts can occur when other values or norms proffered into society will harm them. Conversely there will be integration if the values can be agreed upon by consensus. If the Islamic values that come later are considered to be detrimental, then there will be conflicts when confronted with the local culture forcibly. Whereas, if the Islamic values are viewed in harmony and in accordance with local cultural values then it will be accepted as an integrative social needs.

Further, according to him, the functional theory of change is the relationship between conflict with function in one stability or equilibrium. In his theory of social conflict sharing of conflicts can be explained by referring to certain social structures. Therefore, in the approach of conflict theory must be seen the relationship between conflict with the prevailing social structure. ${ }^{103}$ In this case understand the conflict and the integration of Islamic values with local cultural values in society. When the community is well integrated, it tends to have tolerance and even give space for conflict. On the contrary if people with less degree of integration, tend to be cautious about the emergence of conflict. The orientation of this study is the formation of Islamic values that come later into a new value system by abandoning old local cultural values that are considered contrary to Islamic values.

Interaction of Islamic values with local culture values through approach; conflict or purifikatif.104 Used to examine how local cultural values conflict with Islamic values. The conflict approach is a strictly separating approach between the right and the fool. This approach is the development of rational, critical and scientific thinking. But in the field of muamalah or culture can not use this approach. ${ }^{105}$ Local cultural values that are not in accordance with Islamic values will be rejected, because it can be detrimental and considered contrary to Islamic teachings. According to Wirawan during the fulfillment of the demands for the unity and purity of the true doctrine has not been fulfilled, as long as it is also the struggle of Islam with local culture in the environment is always going on. ${ }^{106}$ This is always the case in Islamic relations with the local

102 Paul B. Horton and Hunt, Chester L, Sociology, Edisi Indonesia, Sosiologi, Terjemahan AminuddinDkk, (Jakarta: Erlangga, 1987),p. 19-20.

103 Nasun,Sistem Sosial, p. 9-25.

${ }^{104}$ Jandra, IslamDalamKontekBudayadanTradisi Plural" dalam Baidhowi dan Jinan (Ed), Agama dan Pluralitas Budaya, p. 72.

105 Simuh, "Interaksi Islam dengan Budaya Jawa" dalam Muhammadiyah dalamKritik, (Surakarta: Muhammadiyah Universitas Press, 2000), p. 149.

106 Wirawan, "Akulturasi Islam-Hindu di Bali: Tinjauan Historis dalam Aswab Mahasin (Ed), Ruh Islam dalam Budaya, p. 237-238. 
culture. Dose Islam always has conflict with the cultural values of local cultural values or otherwise will experience the process of accommodation within certain limits, especially in the rituals of the family life cycle.

\section{Conclusion}

From the theoretical framework it is concluded that the relationship of Islam with local culture can be traced conceptually through the concept of Islamic idealism and Islam reality, which contains Islamic basic values are metaphysical and skularistic. Islamideality (metaphysical)is a permanent Islam sourced from revelation. The concept of reality is guided by the Qur'an and its technical explanation in al-sunnah. The Islamic reality (skularistic) lies in the profane realm of the Islamic value system contained in a number of distinct cultural values, with varied variants, in which Islam is the source of local culture. The dialectical relationship between these two basic Islamic values is understood by the acculturative approach, in the form of accommodation, assimilation and conflict and integration.

\section{Bibliorgaphy}

Saichimurata, Too of Islam, Bandung: Mizan. 2005.

Muhammad 'Abid Al-Jabiri, At-Turrathwa al-Hadarah: DirasahwaMunaqashah, Beirut: al-Markazath-Thaqafi al-'Arabi, tt.

SeyyedHussain Nasr, Islam in The Word: Cultur Diversity Within Spiritual Unity" dalamCultur, 1977, Volume IV, Nomor 1

Bernard Lewis, "Tentang Peradaban Islam" dalam Ulumul Qur'an. Jakarta: Yayasan Paramadina, 1989

Nasr, Islam in The World; Culture Diversity Within SpritualUnity "dalam Culture, 1977, Volume IV, Nomor 1

Parsudi Suparlan, Kebudayaan Masyarakat Agama; Agama sebagai sasaran penelitian Antropologi' dalam Pasudi Suparlan (Ed) Pengetahuan Budaya, Ilmu-ilmu sosial dan Pengkajian Masalah-Masalah Agama, Jakarta: Badan Litbang Departemen Agama, 1982.

Kuntowijoyo, Paradigma Islam Kerangka untuk Interpretasi, Bandung, Mizan, 1989.

Taufik Abdullah, Sejarah dan Masyarakat: Lintasan Historis Islam di Indonesia,Jakarta: Yayasan Obor, 1987.

Arief Mudatsir, Agama dalam Realitas Sosial Masyarakat, dalam Al-Fatah, Palembang: IAIN Raden Fatah Palembang, 1995. 
M. Syafi'I Anwar, Pemikiran dan Aksi Islam Indonesia: Sebuah Kajian Politik Tentang Cendikiawan Muslim Orde Baru, Jakarta: Paramadina, 1995.

Munawir Syadzali, Islam dan Tata Negara, Jakarta: Rajawali Press, 1994.

Karel A. Steenbrink, Indonesia Pasca Reformasi: Angin Segar Bagi Agama Rakyat" dalam Bisnis, Jakarta: Harian Bisnis Indonesia, Nomor 11-12, Tahunke 48, November-Desember, 2000.

Taufik Abdullah dan Sharon Siddiq (Ed) Tradisi dan Kebangkitan Islam di Asia Tenggara, Jakarta: LP3ES, 1989

Soejono, Soekanto, Beberapa Teori Sosiologi tentang Struktur Masyarakat, Jakarta: Rajawali, 1983

Paul B. Horton and Hunt, Chester L, Sociology, Edisi Indonesia, Sosiologi, Terjemahan Aminuddin Dkk, Jakarta: Erlangga, 1987.

Simuh, "Interaksi Islam dengan Budaya Jawa" dalam Muhammadiyah dalam Kritik, Surakarta: Muhammadiyah Universitas Press, 2000 